LEGISLATION AND THE MILK SUPPLY. M ILK legislation, as represented by the Milk 11 and Dairies Bills of 1909 and I9I2, has so far been characterised by a want of detiniteness which has probably been the cause of much of the opposition which it has aroused. This opposition has come about both from the peculiar character of the requirements laid upon the medical officer of health in connection with the inspection, etc., of dairies and cowsheds, and also from the trade itself, on account of the omission of any practical attempt in the earlier Bill to deal with some of the evils which everyone desires to see put right, and from a feeling of uncertainty as to what might happen under the rather extensive powers which that Bill gave to public health authorities. For these reasons the President of the Local Government Board found himself assailed both by the medical officer of health and by representatives of the trade, with the result that in both cases the Bill was eventually dropped. Many of the controversial features of the earlier Bill to which attention was directed were rectified, to a certain extent, in the Bill of 1912, but the powers, etc., of the medical officer of health were not made particularly clearer, and there was still no definite assurance that reforms would be carried out in a satisfactory manner. The chief objection which was raised to both these Bills was that with regard to the principal evils for the rectification of which legislation is so greatly needed, amendment was left in the hands of the Local Government Board by the issue of regulations after the passage of the Bill, and apparently without consultation with anybody.

The problem of drafting a satisfactory Bill is likely to be more difficult than previously, for the conditions of milk supply have changed considerably during the last five years, and the attitude of the farmer must be considered for the successful issue of any milk legislation. It is probably a necessary concomitant of all legislation that it should largely deal with pains and penalties towards those who do not carry out its requirements, but legislation ignores the fact that those so threatened may clear themselves from the fear of such penalties by ceasing to come under the legislation in question, and this is exactly the situation which it is necessary to realise has arisen of late in the milk trade. The farmer, at the present time, is probably rather independent as to whether he produces milk or not. In any case, a large quantity of milk is being produced for purposes other than ordinary milk supply, and these diversions of milk are becoming greater, and it may not be necessary that the same care should be taken with regard to milk which is used for such purposes, as would be the case if the milk were directly used as food material.

To those who are accustomed to deal with farmers on a business basis, it is evident that any attempt to carry out drastic or theoretical alterations in connection with the production of milk would simply result in intense opposition, and a great increase in price for the article supplied.
There is at the present time almost a trades unionism among farmers, by means of which the wholesale price of milk, for no justifiable reason, has been gradually increasing during the last three or four years, and as there appears to be no power which may be invoked which will prevent the farmer increasing his price indefinitely, he would be only too pleased to have some really sound reason to bolster up his present attitude. For this reason the provisions in the earlier Bills which make it incumbent upon the medical officer of health and the sanitary authorities to carry out farm inspection is probably a mistake. The medical officer of health, as a rule, will have little knowledge of farms, cows, and their surroundings, and there usually will be a lack of sympathy between him and the farmer. One looks upon the other as an ignoramus, and the latter regards the former as a theoretical person who knows nothing about the farmer's business. Though the production of a new type of official is to be deprecated, if a special course in sanitary science were added to the ordinary veterinary course, on lines similar to the post-graduate courses which enable a medical man to obtain the diploma in public health, there is no reason why the younger generation of veterinary surgeons should not become amply qualified to carry out farm inspection, while their training would gain for them the respect and sympathy of the farmer.

It is quite certain that much of the present condition of milk production in the country arises more from ignorance than from deliberate intention, and certainly for a year or two after the introduction of any legislation dealing with the production of milk, it would be desirable to proceed with caution, and on the lines of advice and help, rather than upon those of compulsion. Among the younger generation of farmers there are many who will be better able to appreciate the requirements of modern milk production than their forefathers; but as they will probably inherit the typical British obstinacy of the farmer, it would be necessary that they should be led rather than driven.

It must not be forgotten also that the question of improvement of milk production, particularly as regards premises, water supply, etc., is much complicated by the attitude of the owners of the farms, who may be disposed to get rid of farmers from their premises rather than to carry out any very considerable improvements which might be required of them in connection with milk production for food.

It is important in any Bill that the prohibition of the addition of colouring matter and preservatives of any kind should be made, as well as of the addition of skimmed milk to ordinary milk; and with this last might be coupled a further regulation that notices to the effect that such admixture is illegal should be posted in all dairies, in order that employees as well as employers should fully understand that such a regulation is in force. At the present time, a large amount of skimmed milk is 
added to ordinary milk, and such a practice is likely to continue if the present wholesale price or milk holds. Such admixture makes it exceedingly difficult for the honourable trader to compete with his less scrupulous rivals. It would also be well if some regulation were introduced dealing with the question of pasteurisation, and it should be made compulsory that all milk which is pasteurised for sale and constitutes more than, say, 25 per cent. of the total quantity of mixed milk sold, should be labelled "pasteurised," or the knowledge that it has been pasteurised in some way conveyed to the consumer. There is no doubt that the practice of pasteurisation is spreading or account of the more independent and careless attitude of the farmer.

It should also be possible for distributors receiving milk from farmers to ask the public authorities to take samples of any farmer's milk, which for any reason is believed to be adulterated, at the stations on arrival, and for such samples to be analysed, and the proceedings taken against the farmer when necessary, without in any way the name of the distributor being brought into the question, as the present conditions of milk supplv have brought about a position such that the farmer may, if troubled too much by any particular distributor, refuse, on a future occasion, to supply milk to him, and may also very probably notify farmers in the neighbourhood that such and such a buyer is an exacting person or concern, with the result that those distributors who are endeavouring to preserve a high standard may become boycotted.

There appears to be at the present moment a favourable attitude towards the idea of grading milk. However well this may work in America, the result of selling milks of different grades in England will be that milk will deteriorate to the lowest grade, with the exception of quite a small quantity which a few people who wish for milk of a better quality will take. There is plenty of evidence at the present time that the general public buys milk simply on a basis of its price, and without any regard to its quality or source, and it would be most unfortunate if the sale of a low-grade milk were possible. History would repeat itself in this as it has in the case of water in butter, which, since it was made legal to sell r6 per cent. of water in butter, has gradually risen to this limit, though previously the greater number of high-class butters had a considerably smaller percentage of water than 16 per cent. The ordinary householder does not want to be bothered to consider what grade of milk he ought to purchase; he desires to obtain milk which is a reasonably sound commodity which he can consume, without cause for serious apprehension, in the raw state in which he generally prefers it.

A further, and what may prove a serious, obstacle to the improvement of the milk supply looming in the near future, results from the fact that a trades union of milk carriers has recently been formed. One of the principal planks in their platform is that there should be only one delivery on Sundays, which, though quite a laudable idea in itself, would inevitably lead to great deterioration in the bacterıological quality of the milk supplied on Mondays; and from the general attitude of the labour mind, if this point were achieved, it would doubtless occur to them that one delivery every day might also be sufficient, with disastrous resuits so far as the ordinary milk supply is concerned.

It is one thing to legislate and quite another thing to put such legislation into operation when there are such determined labour forces opposing progress. There is no more regrettable feature of the labour world to-day than the steady decay of high principle and honesty of purpose which is making it all but impossible to carry out satisfactorily such rules and regulations as are so necessary in the handling of milk. It is necessary to sue as a favour for that which ought, with right-minded men, to be expected or demanded as a right. This careless attitude, combined with an ignorance of the elementary rules of cleanliness, render the handling of milk a source of constant and harassing worry to the managers of large dairies.

There is also a great lack of cohesion among milk dealers themselves which makes any combined effort for good very difficult of accomplishment, and it must be said with regret that there is also a lack of a right and high ideal in many quarters.

Reverting to the question of legislation, it is desirable that measures should be taken to put a stop to the type of dairyman who carries on his business surreptitiously, who emerges from obscurity when there seems a chance of making some profit at the expense of the legitimate trader, peddles a liquid which has a quite uncertain relation to the cow (and would never be bought by anyone if it were not sold cheaply), and retires again into obscurity when it becomes unprofitable to continue.

With regard to regulations concerning the procedure to be observed in the milking, etc., of cows, the greatest simplicity is essential if there is to be a chance of such procedure being carried out in any real sense, as the times and seasons at which milking has to be done are not conducive to the development of any great enthusiasm with regard to care on the part of the milker. It is hard enough to obtain milkers at the moment, and any great addition to the labour of milking might easily result in a very real dearth of such men. This is, again, a case for careful and patient education rather than for the thunders of legislative pains and penalties.

No Milk Bill has yet shown the least attempt to bring the railway companies into a proper state of mind as to the necessary care and expedition in the carriage of milk.

Since the above was written a new Bill has been introduced into the House of Commons by Mr. Herbert Samuel. Its principal clauses, like its predecessors, are those requiring regulations to be made by the central authority with regard 
to the inspection of cows, cowsheds, and milk shops, the prevention of infection and contamination of milk, the mixing of milk with separated milk or other substances, and conditions of storage and transit. These regulations apparently are to be enforced by a new set of authorities - the county councils instead of the district councils-which is a step in the right direction, and by means of a staff which, in addition to the medical officers of health, is to include veterinary officers and bacteriologists. A sound principle is likewise adopted by making each authority responsible for the milk produced in its own area, and also by enabling the authorities in the town to requisition action by the authorities in the country as a result of bacteriological or other sufficient evidence against the milk. A clause in the Bill introduces a drastic change in the practice of dealing with adulterated milk. Milk is now to be regarded as genuine, however low the percentage of fat, provided it can be proved that it has not been tampered with after leaving the cow. Though not perfect, the present Bill is undoubtedly an improvement on its predecessors, but there seems little prospect of its passing during the present session of Parliament.

\section{R. T. Hewlett}

\section{THE COMMEMORATION OF ROGER} $B A C O N$ AT OXFORD.

THAT the year I214 saw the birth of Roger Bacon is rather a matter of probable inference than of certainty. There is, however, good evidence that he died in 1292 , and was buried on St. Barnabas' Day (June II) in the precincts of the Grey Friars at Oxford, a quarter of the city which is now known as Paradise Square. Hence there was sufficient reason for the celebration at Oxford on June ro of what was called the "seventh centenary" of the great Franciscan, and for the gathering together of representatives from many parts to do honour to the memory of one who, as the unflinching advocate of experimental science as against authority, was held by Humboldt to be "the most important phenomenon of the Middle Ages."

No record appears to exist of the characteristics of Bacon in form and feature. In the statue, however, which was unveiled at the University Museum on June Io, Mr. Hope Pinker has contrived to give the impression of alertness, shrewdness, and pugnacity-qualities which his subject most certainly possessed in full measure. The face also carries a suggestion of humorous depreciation, which sits not inappropriately on the effigy of the man who professed to be able to teach anyone to read Greek in three days, and who would fain have burned all the then existing translations of Aristotle. But whether the sculptor has or has not succeeded in reconstructing the bodily aspect of the real Roger, a point which can never be decided, there is no doubt as to the accuracy of his presentment of the Franciscan garb, or of the astrolabe held in the strenuous grasp of the friar.

In his speech preparatory to the unveiling, Sir
Archibald Geikie laid due stress on the greatness of Roger Bacon as a pioneer of the experimental method in science. "Dispensing with the futile disputational subtleties of the schoolmen of his day, he strove to concentrate attention on things rather than words. He led the way towards the conception of science as the inductive study of nature, based on and tested by experiment." A similar note was struck by Lord Curzon, who in his capacity of Chancellor accepted the statue on behalf of the University of Oxford. After recounting the various branches of learning which Bacon had studied and on which he had written, a list which includes not only nearly all that we understand by physical science, but also moral and political philosophy, the Chancellor went on to

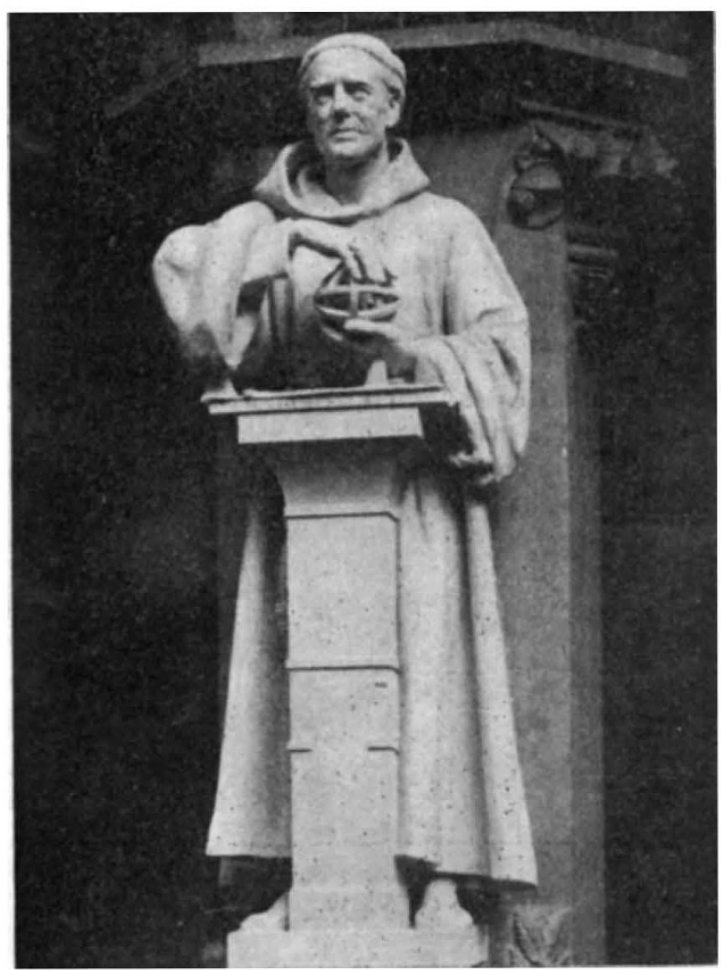

Roger Bacon Statue in the University Museum, Oxford.

point out that in these sciences Bacon was not a mere amateur. "He did not dabble with them, so to speak, in holiday hours, but studied them profoundly." Moreover, he wrote with intense conviction about their essential interdependence one on the other.

Following the ceremony of unveiling, an address was delivered by the Public Orator of the University, Mr. A. D. Godley, of Magdalen College. In elegant Latin periods the orator paid tribute to the diligence and fearlessness which had enabled Roger Bacon to accomplish a great work in the face of difficulties. Turning towards the statue, he exclaimed :-

Welcome, Friar Roger, on your return to Oxford! You here behold the fruit of your labours. . . . Henceforth may your bodily likeness stand in that shrine of science where we witness the fulfilment of your prayers

No. 2329 , VOL. 93] 